\title{
Administrative Background and the Process of Migrant Integration in Hungary
}

\section{Istrán Temesi*}

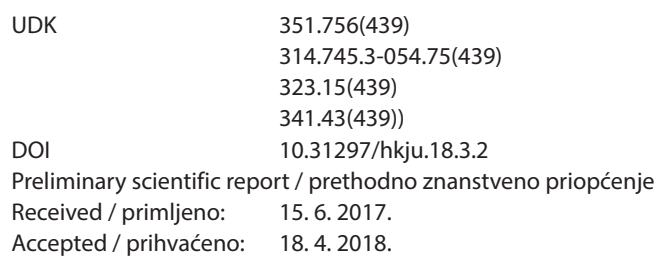

Some EU countries have been migrant destinations for a long time, while others have lost a considerable part of their population since their accession. Hungary belongs to the latter. Large numbers of immigrants have not been arriving here since the end of the wars in former Yugoslavia. In 2015 Hungary was strongly affected by mass migration, mainly because of its geographical location. Mass migration strongly influenced politics as the decision-maker and public administration as the executor of political decisions. Both the decisions and the policy-makers have been strongly criticised for taking a different approach to the situation compared with many other European countries. The Hungarian government's priority was to reduce or stop mass migration and they used political, legal, and physical instruments selected for this purpose. This study does not aim to judge whether they are right or wrong.

István Temesi, Associate Professor, National University of Public Service, Budapest, Hungary (izvanredni profesor na Nacionalnom sveučilištu za javne službe, Budimpešta, Mađarska, e-mail: temesi.istvan@uni-nke.hu)

ORCID ID: https://orcid.org/0000-0002-6686-3007 
Keywords: administrative procedure, asylum, immigration authority, mass migration, procedure on the spot, refugees

\section{Introduction: Political and Legal Background}

To understand the situation regarding mass migration in Hungary, it is necessary to be familiar with the political and social background. A question of primary importance is the official government policy with regard to the migration issue. The official political will represented by the government is to control and prevent illegal migration, as well as to control legal migration. The tables show the number of asylum-seekers ${ }^{1}$ arriving in Hungary in recent years.

Table 1. Changes in the number of asylum-seekers arriving in Hungary 2014-2015

\begin{tabular}{|l|r|r|r|r|}
\hline & 2014 & 2015 & Change & $\begin{array}{c}\text { Change } \\
\text { in \% }\end{array}$ \\
\hline Total number of registered asylum-seekers & 42,777 & 177,135 & 134,358 & $314.09 \%$ \\
\hline European & 21,865 & 25,170 & 3,305 & $15.12 \%$ \\
\hline Non-European & 20,912 & 151,965 & 131,053 & $626.69 \%$ \\
\hline $\begin{array}{l}\text { Share of Europeans in total number of } \\
\text { registered asylum-seekers in \% }\end{array}$ & $51.11 \%$ & $14.21 \%$ & & $16.89 \%$ \\
\hline $\begin{array}{l}\text { Share of non-Europeans in total number of } \\
\text { registered asylum-seekers in \% }\end{array}$ & $48.89 \%$ & $85.79 \%$ & & $-16.89 \%$ \\
\hline
\end{tabular}

Table 2. Changes in the number of asylum-seekers arriving in Hungary 2015-2016

\begin{tabular}{|l|r|r|r|r|}
\hline & \multicolumn{1}{|c|}{2015} & 2016 & Change & $\begin{array}{c}\text { Change } \\
\text { in \% }\end{array}$ \\
\hline Total number of registered asylum-seekers & 177,135 & 29,432 & $-147,703$ & $-83.38 \%$ \\
\hline European & 25,170 & 635 & $-24,535$ & $-97.48 \%$ \\
\hline Non-European & 151,965 & 28,797 & $-123,168$ & $-81.05 \%$ \\
\hline $\begin{array}{l}\text { Share of Europeans in total number of } \\
\text { registered asylum-seekers in \% }\end{array}$ & $14.21 \%$ & $2.16 \%$ & & \\
\hline $\begin{array}{l}\text { Share of non-Europeans in total number of } \\
\text { registered asylum-seekers in \% }\end{array}$ & $85.79 \%$ & $97.86 \%$ & & \\
\hline
\end{tabular}

${ }^{1}$ Asylum: legal grounds for staying in the territory of Hungary and simultaneous protection against refoulment, expulsion, and extradition; definition by Legislative Act No. LXXX of 2007 on Asylum, Art. 2., point c). 
Source: Table 1 and 2 have been prepared by the author using official data provided by the Hungarian Immigration and Asylum Office. The data have been retrieved from the official site of the Hungarian Immigration and Asylum Office: http://www.bmbah.hu/index.php?option=com $\mathrm{k} 2 \& \mathrm{view}=$ item\&layout=item\&id=492\&Itemid $=1259 \&$ lang $=$ en $\#($ accessed 28. 03. 2017).

In 2015 the total number of asylum-seekers $(177,135)$ more than tripled in comparison with 2014 (42,777). The higher number itself made the government act but the manner in which most of these people arrived in the country influenced the government's policy even more. The result of these measures may also be seen in 2016, if we consider only the number of migrants arriving in the country $(29,432)$.

Before we proceed, the term illegal migration should be defined. Considering the number of migrants in 2015 and 2016, it is important to stress that most had no intention of staying in Hungary and waiting for the authorities to decide on their requests for asylum. Some migrants did apply for asylum but did not wait for the official decision, whilst many passed through the country without either registering or claiming asylum, which meant that the authorities were unable to follow up on who they were and where they had gone.

That is why the Hungarian government took harsh measures to control the situation. The basis of these measures should be examined before an attempt to understand them.

\subsection{Principles of the Hungarian Government's Policy on Migration}

Considering the fact that many of the incoming persons who claimed to be asylum-seekers subsequently left the country without receiving a decision on their request, if such a request had been submitted, the Hungarian government made a clear distinction between refugees and migrants. Consequently, all refugees are migrants but not all migrants may qualify as refugees.

The government makes the point that a refugee can only be a person under the Geneva Convention of $1951 .^{2}$ Most people crossing the Hungarian border do not have this status and some did not even intend to obtain it. Based on Art. 1, Section (2) of the Convention Relating to the Status of Refugees signed in Geneva on 28 July 1951, a refugee is a person who, "owing to well-founded fear of being persecuted for reasons of race, religion, nationality, membership of a particular social group or political opinion, is outside the country of his nationality and is unable or, owing to such fear, is unwilling to

${ }^{2}$ Convention Relating to the Status of Refugees signed at Geneva, on 28 July 1951. 
avail himself of the protection of that country; or who, not having a nationality and being outside the country of his former habitual residence as a result of such events, is unable or, owing to such fear, is unwilling to return to it."

Legislative Act No. LXXX of 2007 on Asylum Art. 6, Section (1) defines a refugee as follows: Hungary shall recognise as a refugee a foreigner who complies with the requirements stipulated by Art. XIV Section (3) of the Fundamental Law.

Art. XIV Section (3) of the Fundamental Law of Hungary sets out that Hungary shall grant asylum to all non-Hungarian citizens as requested, if they are being persecuted or have a well-founded fear of persecution in their native countries or in the countries of their usual residence due to their racial or national identities, affiliation to a particular social group, or to their religious or political persuasions, unless they receive protection from their countries of origin or any other country.

\subsection{The Question of Different Migrant Statuses}

Legislative Act No. LXXX of 2007 on Asylum distinguishes between several statuses other than that of a refugee. This is important because not only refugees enjoy asylum in Hungary. Legislative Act No. LXXX of 2007 on Asylum Art. 3, Section (2) provides that a person recognised by Hungary as a refugee or as a beneficiary of subsidiary or temporary protection shall have the right to asylum. Consequently, there are three categories of asylum-seekers enjoying asylum: refugee, beneficiary of subsidiary protection, and beneficiary of temporary protection, whilst a fourth status is that of a person authorised to stay. This last category qualify as asylum-seekers too. It is important to note that a migrant may be a person who does not belong to any of these categories because of their lack of intention to stay in Hungary and enjoy protection.

A beneficiary of subsidiary protection is defined by Art. 12, Section (1) of Legislative Act No. LXXX of 2007 on Asylum as follows: "Hungary shall grant subsidiary protection to a foreigner who does not satisfy the criteria of recognition as a refugee but there is a risk that, in the event of his/her return to his/her country of origin, s/he would be exposed to serious harm and s/he is unable or, owing to fear of such risk, unwilling to avail himself/ herself of the protection of his/her country of origin". ${ }^{3}$

${ }^{3}$ Unofficial translation of the Legislative Act No. LXXX of 2007 on Asylum http:// www.refworld.org/docid/4979cc072.html 
A beneficiary of temporary protection is defined by Art. 19 of Legislative Act No. LXXX of 2007 on Asylum as follows: Hungary shall grant temporary protection to a foreigner who belongs to a group of displaced persons arriving in the territory of Hungary en masse which was recognised a) by the Council of the European Union as eligible for temporary protection under the procedure determined in Council Directive 2001/55/EC of 20 July 2001 on minimum standards for giving temporary protection in the event of a mass influx of displaced persons and on measures promoting a balance of efforts between Member States in receiving such persons and bearing the consequences thereof (hereinafter: Directive 2001/55/EC), or b) by the Government as eligible for temporary protection as the persons belonging to the group who had been forced to leave their country due to an armed conflict, civil war or ethnic clashes or the general, systematic or gross violation of human rights, in particular, torture, cruel, inhuman or degrading treatment.

A person authorised to stay is defined by Art. 25/A of Legislative Act No. LXXX of 2007 on Asylum as follows: Hungary shall grant protection to a foreigner who does not satisfy the criteria of recognition as a refugee or as a beneficiary of subsidiary protection but there is a risk that, in the event of his/her return to his/her country of origin, he/she would be persecuted or would face the danger of a death sentence, torture or any other inhuman treatment or punishment due to their racial or national identities, affiliation to a particular social group, or to their religious or political persuasions and there is no safe third country that would give him/her temporary protection.

\subsection{The Question of Safe Country of Origin and Safe Third Country}

The main criteria for someone to be recognised as a refugee or another person to be granted protection are safe country of origin and safe third country. In Hungary asylum cannot be granted if the asylum-seeker arrives from a country that is considered to be safe. In this case, it is assumed that the person has left their country of origin of their own will and he or she has not been forced to flee by the situation described in the Geneva Convention or in the legislative act as defined above.

Legislative Act No. LXXX of 2007 on Asylum defines a safe country of origin as one included in the shared minimum list of third countries regarded as safe countries of origin approved by the Council of the European Union or in the national list stipulated by a government decree of some of these countries. The presence of the country of origin on any of such lists is a rebuttable presumption with regard to the applicant, according to which no persecution is experienced in general and systematically in that country or in a part 
of that country; there is no threat of generalised violence in the context of international or national conflict situations; no torture, cruel, inhuman or degrading treatment or punishment is applied; and an efficient system of legal remedy is in place to address any injury of such rights or freedoms.

The definition of a safe third country is given by Legislative Act No. LXXX of 2007 on Asylum as a country in connection to which the refugee authority has ascertained that the applicant is treated in line with the following principles:

- their life and liberty are not jeopardised for racial or religious reasons or on account of their ethnicity/nationality, membership of a social group or political conviction, and the applicant is not exposed to the risk of serious harm;

- the principle of non-refoulment is observed in accordance with the Geneva Convention;

- the rule of international law, according to which the applicant may not be expelled to the territory of a country where they would be exposed to treatment/behaviour stipulated by Art. XIV, Section 2 of the Fundamental Law, and

- the option to apply for recognition as a refugee is ensured, and in the event of recognition as a refugee, protection in conformity with the Geneva Convention is guaranteed.

The importance of these definitions can be inferred from the Hungarian government's policy implemented by the authorities in the way that asylum is not granted to the asylum-seeker in at least two cases. If one leaves their safe country of origin, this means that they had another reason than those recognised by the Geneva Convention or by the Hungarian legislative act and consequently they do not need protection. The other case is when one is forced to leave their home country due to the circumstances defined by the Geneva Convention and the Hungarian legislative act and does so, but on leaving the country or countries where they have been threatened, they pass through one or more safe countries prior to their arrival in Hungary. In this case the migrant has already missed the opportunity to seek asylum on the first possible occasion, although he or she has arrived in a safe country where they could have done so.

\section{Political Decisions}

In Hungary mass migration occurred in 2015 , as evidenced by the increase in the number of asylum-seekers. The exact number of migrants who neither registered nor officially applied for asylum is not known but it is much higher 
than statistics indicate. Prior to September 2015, Hungarian authorities did not know how many persons had crossed the borders of the country and who these persons were. Most migrants crossed the border illegally as opposed to checkpoints and then left Hungary in the same way. It was obvious that most of them intended to simply pass through Hungary and subsequently Austria, en route to countries in Western Europe. Illegal migration gave rise to criminal activity, including the organised travel of these people from one country to another, as well as crossing state borders without permits or control.

The Hungarian government then made decisions in order to control and stop illegal migration. However, although these instructions did stop illegal migration, they also became the target of criticism because it was made difficult for threatened people to claim asylum in cases when this was really necessary. Government measures were partly taken in the form of actions on the spot, i.e., at the borders of the country, while others were realised in the form of rule-making. Both entered into force on $15 \mathrm{Sep}-$ tember 2015, followed by others - the latest passed on 28 March 2017.

\subsection{Legislation}

New Legal Rules as of 15 September 2015. On 4 September 2015, the Hungarian Parliament passed Legislative Act No. CXL of 2015 on the Modification of Certain Legislative Acts Related to the Management of Mass Migration. This legislative act modified ten further legislative acts, including the Penal Code and the Criminal Procedure, as well as the Legislative Act on Asylum.

One of the most important changes was the criminalisation of certain activities and the amendment of the Penal Code. Consequently, passing through and damaging the border barrier, as well as hindering the construction of the border barrier were qualified as criminal offences by the Penal Code and became forbidden and punishable by detention or expulsion. ${ }^{4}$ Furthermore, punishment for the criminal offence of people-smuggling (or migrant-smuggling) became more severe.

The Legislative Act on Criminal Procedure was modified as well. Special rules of the procedure became applicable in cases of criminal offences related to the border barrier. ${ }^{5}$

${ }^{4}$ Legislative Act No. C of 2012 on the Penal Code. Art. 352/A Illegal passage through border barrier, 352/B Damaging border barrier, 352/C Hindering works related to border barrier.

${ }^{5}$ Chapter XXVI/A of Legislative Act No. XIX of 1998 under the title Procedure in the Case of Criminal Offences Related to Border Barrier. 
Legislative Act No. LXXX of 2007 on Asylum was modified in the way that it introduced the institute of crisis caused by mass migration and determined its criteria. ${ }^{6}$ The act authorised the government to declare a crisis caused by mass migration by decree and to set the rules concerning the mandate, expiration, and revocation of such a situation. The government then issued Decree No. 269 of 15 September 2015 on the Declaration of Crisis Caused by Mass Migration, including the Rules Concerning the Mandate, Existence, and Revocation of Such Situation. In this decree the government declared a state of crisis caused by mass migration between 15 September 2015 and 15 March 2016. Then the government issued Decree No. 41 of 9 March 2016 under the same title: the Declaration of a State of Crisis Caused by Mass Migration in the Territory of Hungary, including the Rules Concerning the Mandate, Existence and Revocation of Such Situation, which declared a state of crisis between 10 March and 9 September 2016. On 5 September 2016, the government extended the duration of the decree until 8 March 2017, and on 6 March of that year the decree was amended to modify the date of expiration again, this time until 7 September 2017.7 This situation can be declared to relate to the whole country or just a part of the country's territory.

Modification of Legislative Act No. LXXX of 2007 on Asylum introduced the status of a "person authorised to stay", as described above.

In addition, this legislative act was considerably amended by the introduction of new rules of procedure concerning the recognition of the claimant as a refugee or beneficiary of subsidiary protection, called "procedure on the spot". ${ }^{8}$ The rules of the immigration authority's procedure are determined by Chapter VIII of the Act on Asylum, under the title "Procedure Aimed at Recognition of Applicant as Refugee or as Beneficiary of Subsidiary Protection". The new institution is a proceedings on the spot, which may be initiated if the claim is submitted by a migrant before he or she crosses the border or if the asylum-seeker is stopped within 8 kilometres from the border in Hungarian territory, as well as if their claim is submitted in the transit zone.

${ }^{6}$ Crisis Caused by Mass Migration as a new subtitle was integrated into the Chapter IX of the Act "Procedure Aimed at Recognition as Beneficiary of Temporary Protection".

7 Art. 1 of Government Decree No. 36. of 6 March 2017 on the modification of Government Decree No. 41 of 9 March 2016 on the Declaration of Crisis Caused by Mass Migration in the Territory of Hungary including the Rules Concerning the Mandate, Existence and Withdrawal of Such Situation.

8 Art. 71/A of Legislative Act No. LXXX of 2007 on Asylum. 
New Legal Rules as of 28 March 2017. The most recent modifications to the legal rules on asylum entered into force on 28 March 2017. One of the main points is the latest amendment to Act No. LXXX of 2007 on Asylum, which integrated new and special rules of procedure into the act as Chapter IX/A. This new chapter of the act under the title "Rules of Procedure in Crisis Caused by Mass Migration" ${ }^{\prime}$ contains new special rules of administrative procedure and judicial revision of the authority's administrative decision. If the government declares a state of crisis caused by mass migration in the way that is described above, only these new and special procedural rules are applicable; i.e., general rules of procedure cannot apply.

The new legal rules permit asylum-seekers to submit their request for asylum only in person and only in the transit zone established next to the border. They must also wait for the decision of the authority in this zone. This also means that asylum-seekers cannot cross the border and stay in the country while their request is being processed. In this case, asylum-seekers are authorised to leave the transit zone, but only in the direction of the neighbouring country.

If an asylum-seeker has entered the country illegally, is arrested by police, and declares his or her intention to submit a request for asylum, they will be conducted via a border checkpoint into the transit zone, while the application is processed. An applicant staying in the transit zone and waiting for a decision on his or her request is not entitled to stay in the territory of Hungary under the conditions set forth in the Act on Asylum, nor are they entitled to a permit which would authorise their stay in the territory of Hungary as defined in a separate law.

The administrative procedure of legal remedy against the decision rejecting an asylum claim has become shorter. The applicant should submit the request for legal remedy within three days from the disclosure of the decision, and the authority should forward the request for remedy to the court, along with the case file, within three days. Consequently, the administrative actions before judicial revision of the administrative decision are performed more quickly.

A new rule is that the immigration authority shall decide on the basis of the information available or shall stop the detailed procedure if the applicant: withdraws his or her application in writing, refuses to issue a decla-

9 "Rules of Procedure in Crisis Caused by Mass Migration" as a title used to be part of Chapter IX of the act as Art. 80/A, and became a separate chapter from 28 March 2017. 
ration, hinders the authority in attempts to fingerprint or photograph him or her, and/or leaves the transit zone. Any of these conditions alone serves as a basis to discontinue the procedure. The decision on the closure of the procedure cannot be revised upon request.

A new procedural rule set out by the Act on Asylum is that the interview with the asylum-seeker by a judge must be held in the transit zone or via telephone in the course of the procedure for remedy before the court. Furthermore, if legal remedy against a decision is not possible, the asylum-seeker is forced to leave the transit zone.

If an applicant submits their second application after the adoption of a final and absolute decision of discontinuation or rejection, they are not entitled to any of the following: to stay in the territory of Hungary under the conditions set forth in the Act on Asylum or a permit authorising their stay in the territory of Hungary as defined in a separate law; the provisions, benefits and accommodation under the conditions determined in the Act on Asylum and in a separate law; nor to work at the reception centre within nine months of the submission of the application for recognition. This last prohibition is imposed by the general rules applicable to foreigners (rather than the Act on Asylum) at any point after the nine-month period.

\subsection{Closing the Borders}

On 17 June 2015, the government published Resolution No. 1401/2015. (VI.17.), which ordered that a border barrier be built. The construction of the 175-kilometre (109-mile) long and 4-metre (13-foot) high temporary barrier started in early July 2015 and was completed by 14 September, sealing the border between Hungary and Serbia as a consequence. At the same time, two camps to house asylum applicants (reception centres) were constructed. The immediate impact of the barrier was to block migrants unwilling to apply for refugee status in Hungary from entering the country. The fence closed off the border in the countryside, between official border checkpoints.

As a natural reaction, the migrants modified their route and began arriving in Hungary from Croatia. That was why the Hungarian government ordered the construction of a second fence along Hungary's border with Croatia on 18 September 2015. On 16 October 2015, the fence along the 348-kilometre (216-mile) border with Croatia was completed.

The number of attempted border entries has fallen tremendously since the barrier was constructed. During the month of September 2015 there 
was a total number of 138,396 migrant entries, and by the first two weeks of November the average daily number of intercepted migrants decreased to only 15, which is a daily reduction of more than 4,500. In April 2016, the Hungarian government announced the strengthening of the barrier.

An important new rule was introduced in Legislative Act No. XXXI. of 1997 on the Protection of Children: children between the ages of 14 and 18 arriving in Hungary without an adult in a declared state of crisis of mass migration must also stay in the transit zone during the procedure of the immigration authority. This meant that only minors under 14 would be transferred to special centres for children.

\section{Administrative Background and Integration}

\subsection{Administrative Capacities}

Since the summer of 2015 the Hungarian government has not only been focusing on legislation but on administrative capacities as well. As we have seen, the administrative capacities of the country were used and strengthened first to control and then to stop illegal migration into Hungary, considering public administration follows orders resulting from political decisions. Organisations of public administration dealing with migration were reorganised and developed by the government.

Immigration and Asylum Office. The main actor in the migration issue is the Immigration and Asylum Office..$^{10}$ It has been operating under this name since 1 January 2017 as an assignee of the Office of Immigration and Nationality. ${ }^{11}$ One of the reasons for structural change is the fact that citizenship affairs and nationality affairs like name change procedures have been delegated to the authority of governmental territorial representatives. Consequently, affairs related to immigration and asylum have remained within the remit of this authority, whose new name reflects its functions. The Immigration and Asylum Office has its central headquarters and seven regional offices called directorates. Their services are available to the public in 24 front offices.

\footnotetext{
lum Office.

11 Its predecessor, the Office of Immigration and Nationality, was established under
}

${ }^{10}$ Government Decree No. 361/2016. (29. November) on the Immigration and Asythis name on 1 January 2000. See Government Decree No. 162/1999. (19 November). 
The Office has reception centres and secure reception centres (closed refugee reception centres) under its supervision. Besides the two reception centres founded earlier in Bicske and Vámosszabadi, three further temporary centres were established in 2016 (Nagyfa, Körmend, and Kiskunhalas), but the operation of one of these was suspended in March 2017 (Körmend). There are three secure reception centres for asylum detention $^{12}$ - also called closed refugee reception centres - Békéscsabán, Nyírbátor, and Kiskunhalas.

A reception centre is an independent organisational unit which has the full power of disposition in terms of the budget allocation chapter under the supervision of the director general. The tasks and responsibilities of a reception centre cover the following: provision of accommodation and services in accordance with the relevant legislation for foreign nationals requesting asylum, subsidiary or temporary protection, and for those already admitted; fulfilment of its statutory obligation to provide information and the obligation of reporting on relating to the centre's residents as provided for by legislation and the Immigration and Asylum Office; ensuring the rights of the centre's residents and keeping records in accordance with the on Asylum.

${ }^{12}$ Criteria of ordering asylum detention is regulated by Art. 31/A of Legislative Act

The refugee authority may take into asylum detention a person seeking recognition, whose right of residence is only based on the submission of an application for recognition if

- the identity or nationality of the person seeking recognition is not clarified, in order to establish it;

- the person seeking recognition has been hiding from the authority or has been obstructing the course of the asylum procedure in another manner;

- there are well-founded grounds to presume that the person seeking recognition is delaying or frustrating the asylum procedure or presents a risk of absconding, in order to establish the data required to conduct the asylum procedure;

- the detention of the person seeking recognition is necessary in order to protect national security, public safety, or - in the event of serious or repeated violations of the rules of the compulsory designated place of stay - public order;

- the application has been submitted in an airport procedure; or

- the person seeking recognition has not fulfilled his/her obligation to appear on summons, and is thereby obstructing the Dublin procedure.

Asylum detention may not be ordered for more than 72 hours. The refugee authority may present a motion for the extension of asylum detention in excess of 72 hours within 24 hours of the ordering of detention, at the local court which is competent according to the place of detention. The court may extend the period of detention by 60 days at most, and this period may be extended for another 60 days at the request of the refugee authority, in such a manner that the period of detention may not exceed six months, even in such cases. The motion for extension shall be received by the court no later than within eight working days before the date when the period shall be extended. The refugee authority shall justify its motion. 
relevant legislation for the purpose of the assessment of eligibility for aid and support provided under the relevant legislation; provision of appropriate circumstances as specified by the Immigration and Asylum Office for administrative proceedings; cooperation with municipal governments, non-governmental organisations, and churches participating in providing services to refugees, as well as with law enforcement agencies and national security services in order to perform its tasks specified in the relevant legislation; decisions on health screening and primary health care services for the centre's residents as prescribed by the public health authority; organisation of programmes for the centre's residents to facilitate the efficient spending of their free time; provision of a common room, principally for the purpose of worship; implementation of the reception centre's share of the programmes and activities introduced for the purpose of the integration of refugees and beneficiaries of subsidiary protection; promotion of voluntary repatriation or departure to third countries; provision of information and guidance to help solve residents' everyday problems, as well as advisory services relating to life management; and assistance provision where appropriate for children to partake in public education. ${ }^{13}$

A closed refugee reception centre (secure reception centre) is an independent organisational unit which has the full power of disposition in terms of the budget allocation chapter under the supervision of the director general. The tasks and responsibilities of a closed refugee reception centre are similar to those of a reception centre. In addition to the tasks and responsibilities of a reception centre listed above, closed refugee reception centres are also responsible for execution of detention of a foreign national seeking asylum so as to ensure his/her availability in the course of the asylum procedure; provision of accommodation and services in accordance with the relevant legislation for asylum-seekers or those seeking subsidiary or temporary protection held in custody; fulfilment of its statutory obligation to provide information and the obligation of reporting on the centre's residents as provided for by legislation and the Immigration and Asylum Office; ensuring the rights of the centre's residents and the execution of detention, and keeping records in accordance with the relevant legislation for the purpose of the assessment of eligibility for aid and support provided under the relevant legislation; decisions on health screening and primary health care services for the centre's residents as prescribed by the public health authority; 24-hour aid provision to be giv-

13 Retrieved from http://www.bmbah.hu/index.php?option=com_k2\&view=item\&lay out=item\&id=539\&Itemid $=1287 \&$ lang=en\# (accessed 13. 04. 2017). 
en by social workers and information and guidance to help solve residents' everyday problems, as well as advisory services relating to life management; assistance provision where appropriate for children to partake in public education and performance of its delegated duties in child protection; organisation of programmes for the centre's residents to facilitate the efficient spending of their free time; provision of a common room, principally for worship; provision of a means of communication for the asylum-seeker in custody; cooperation with the national and international government, local government, civil society and other organisations, churches providing services for the centre's residents, and also with the law enforcement agencies and the national security services in order to perform its tasks delegated by law; and promotion of voluntary repatriation or departure to third countries. ${ }^{14}$

The Immigration and Asylum Office is the authority entitled to issue licences to foreigners to enter, reside and settle in Hungary, as well as to decide upon requests for asylum. Although both the structure of the immigration authority and its name have been changed, the reason for this change has not been mass migration, but rather the reorganisation of task allocation within the Hungarian public administration. Affairs of aliens have been separated from those of citizens, such as name change procedures. These changes are considerable in the procedure of the Immigration and Asylum Office, which was modified due to migration in 2015 and 2017. These changes to procedural rules are presented above.

The Police. The Hungarian police - like the military - has been strengthening its presence at the borders of the country due to mass migration since 2015. Police forces were sent to the southern border when the number of migrants increased in 2015. This happened again when the border was physically closed off by a fence. As the barrier was extended and strengthened, some of the police forces were withdrawn and military forces became involved too.

In August 2016, the government declared that police forces specialising in border defence should be strengthened and a decision on the recruitment of 3,000 personnel was made. On 3 February 2017, the government adopted Resolution No. 1043/2017. (3 of February) and ordered the financing of the increase in police personnel, which thus made possible the recruitment of 3,000 persons for border defence units.

14 Retrieved from http://www.bmbah.hu/index.php?option=com_k2\&view=item\&lay out $=$ item $\&$ id $=537 \&$ Itemid $=1285 \&$ lang $=$ en $\#($ accessed 13.04 .2017$)$. 


\subsection{Integration of Asylum-Seekers}

The legal rule on migration of primary importance is Legislative Act No. LXXX of 2007 on Asylum. Legislative Act No. LXXX of 2007 on Asylum provides for the rules of

- the content of the asylum granted by Hungary

- the criteria of recognition as a refugee

- the criteria of recognition as a beneficiary of subsidiary protection

- the criteria of recognition as a beneficiary of temporary protection

- the criteria of recognition as a person authorised to stay

- the procedure aimed at recognition and the revocation thereof

- the procedure aimed at expulsion by the authority and the revocation thereof.

The provisions of this act apply to foreigners who have submitted applications for recognition or who enjoy asylum. A person recognised by Hungary as a refugee or as a beneficiary of subsidiary or temporary protection enjoys asylum.

\subsection{Rights and Duties of Persons Seeking Recognition}

The main rules of the rights and duties of persons seeking recognition are regulated by Legislative Act No. LXXX of 2007 on Asylum. All these persons are entitled to:

- stay in the territory of Hungary under the conditions set forth in the act and to a permit authorising their stay in the territory of Hungary as defined in a separate law;

- provisions, benefits, and accommodation under the conditions determined in the act and in a separate law;

- work at the reception centre within nine months of the submission of the application for recognition, when nine months have passed, employment is regulated by the general rules applicable to foreigners;

- enter into and maintain contact with the United Nations High Commissioner for Refugees (UNHCR) and other international or non-governmental organisations during the term of the asylum procedure.

These persons are obliged to:

- cooperate with the refugee authority; in particular, to reveal the circumstances of their flight, communicate their personal data and fa- 
cilitate the clarification of their identity, and to hand over their documents;

- issue a declaration with respect to their property and income;

- take up habitual residence at the place of accommodation designated by the refugee authority for him or her according to the act, and observe the rules of conduct governing residence at the designated place of accommodation;

- take required health tests, medical treatment prescribed as mandatory by law or required by the health authority and, unless they have been vaccinated previously, receive any vaccinations prescribed as mandatory by law and/or required by the health authority in the case of danger of disease.

The importance of the four different statuses is that migrants of different statuses seeking asylum have different rights and duties regulated by the Act on Asylum.

Refugee. A refugee has the same rights and obligations as a Hungarian citizen, with exceptions expressly set out by legislative acts or government decrees. The Act on Asylum enumerates the exceptions of primary importance. A refugee has suffrage in the elections of local municipality representatives, mayors, and in local referenda; however, they do not have suffrage in parliamentary elections or national referenda. They may not hold a job or responsibility and may not hold office, because this is restricted by law to those of Hungarian nationality.

The main rights refugees are entitled to are the following:

- an identity card determined in a separate law and a bilingual travel document specified by the Geneva Convention, insofar as no reasons of national security or public order bar the issuance of such a document;

- provisions, benefits, and accommodation under the conditions determined in the Act on Asylum and in a separate law.

It is important to note that refugees had been entitled to support which facilitated their integration into society before 1 June 2016. This service was suspended by Legislative Act No. XXXIX of $2016^{15}$ that amended the Act on Asylum.

A refugee is obliged to:

- cooperate with the refugee authority;

15 Art. 90, point b) of Legislative Act No. XXXIX of 2016 on the Modification of Certain Legislative Acts Related to Refugee Affairs as well as of acts linked with this Issue. 
- take health tests, medical treatment prescribed as mandatory by law or required by the health authority and, unless they have been vaccinated previously, receive any vaccinations prescribed as mandatory by law and/or required by the health authority in the case of danger of disease; - respect the laws and regulations of Hungary.

Beneficiary of Subsidiary Protection. A beneficiary of subsidiary protection has the rights and obligations of a refugee with exceptions expressly set out by legislative acts or government decrees, including the main exceptions determined by the Legislative Act on Asylum. Contrary to the rules which apply to refugees, a beneficiary of subsidiary protection is entitled to a travel document determined in a separate legal rule and for reasons of national security or public order the issuance of such a document may be refused. ${ }^{16}$ This means that beneficiaries of subsidiary protection do not receive an identity card. The further main differences are that a beneficiary of subsidiary protection does not have suffrage and that beneficiaries of subsidiary protection are not entitled to the preferential conditions ${ }^{17}$ applicable to refugees regarding nationalisation.

The refugee authority shall review the existence of criteria of eligibility for subsidiary protection at least every three years following recognition. This provision of the Act on Asylum was amended in 2016. Prior to 1 June 2016, the existence of the criteria was reviewed at least every five years following recognition. ${ }^{18}$

Beneficiary of Temporary Protection. A beneficiary of temporary protection is entitled to the following:

- a document verifying their identity (which is not the same as a Hungarian identity card);

- a travel document, as determined in separate legal rule, authorising a single exit and return, if they have no valid travel document from their country of origin;

- provisions, benefits, and accommodation under the conditions determined in the Act on Asylum and in a separate law;

- employment according to general rules applicable to foreigners.

16 The authority's decision on the refusal to issue a travel document is subject to judicial review.

17 One of the main preferential conditions applicable to refugees regarding nationalisation is that one is only required to have lived in Hungary permanently for three years instead of eight.

18 Art. 14, Section 1 of Legislative Act No. LXXX of 2007 on Asylum. 
A beneficiary of temporary protection is obliged to:

- report their place of accommodation and any change therein to the refugee authority;

- cooperate with the refugee authority;

- take required health tests, medical treatment prescribed as mandatory by law and/or required by the health authority, and unless they have been vaccinated previously, receive any vaccinations prescribed as mandatory by law and/or required by the health authority in the case of danger of disease;

- respect the laws and regulations of Hungary.

Person Authorised to Stay. As a consequence of the migration crisis, the rules of Legislative Act of 2007 on Asylum concerning this status were modified in 2016.

The status of a person authorised to stay is recognised by the Immigration and Asylum Office's decision. The recognition criteria are as follows:

- the Immigration and Asylum Office has decided on protection against refoulement in its final decision in an aliens-policing procedure or

- request for asylum was refused but protection against refoulement was decided on at the same time.

The authority revises the existence of status criteria each year, which is not a rule in the case of the other three statuses.

Criteria of the prohibition of refoulement are determined by the Act on Asylum. The prohibition of refoulement (non-refoulement) prevails if the person seeking recognition is exposed to the risk of persecution due to reasons of race, religion, ethnicity, membership of a particular social group or political opinion, or to treatment/behaviour determined in Art. XIV, Section (2) of the Fundamental Law and there is no safe third country which would receive them.

Another case is that of the unaccompanied minor. The prohibition of refoulement also prevails if either family unification or any state or other institutional care is impossible, either in the minor's country of origin or in another state that would accept them.

In the event of the existence of prohibition in one of these cases, the Immigration and Asylum Office must recognise the foreigner as a person authorised to stay. In its decision relating to the refusal of an application for recognition or the revocation of recognition, the refugee authority shall establish whether the prohibition of refoulement prevails or not.

A person authorised to stay is entitled to receive all the benefits available to national permanent residence permit holders, as well as provisions and 
benefits under the conditions determined in the Act on Asylum and in a separate law.

\subsection{Conditions of Reception: Common Rules for the Four Statuses}

All persons seeking recognition, i.e., all those belonging to any of the four status categories, have some common rights called conditions of reception. ${ }^{19}$ These are material conditions of reception, as well as rights and measures concerning freedom of movement, health care, social care, education. These issues are determined in detail by further laws.

As general rule, a person seeking recognition is entitled to material conditions of reception and other forms of assistance which correspond to their health conditions and satisfy their basic needs. Another principle is that of personal need, which means that a person must be eligible for aid and support. All persons seeking recognition are entitled to the provision of these conditions of reception free of charge in case of need, as determined by a government decree. If the person seeking recognition does not qualify as needy - in particular if they have permanent employment - the refugee authority may, in whole or in part, require the reimbursement of material conditions of reception and the cost of health care services. If it is shown that the person seeking recognition had sufficient funds for material conditions of reception and/or for health care services, while the same were provided to them by the refugee authority, the authority may order the person seeking recognition to reimburse these costs.

A foreign national seeking asylum is considered eligible for aid and support, if the person seeking recognition, or their spouse or next of kin living in the same household, have no assets available in Hungary whereby to support themselves, and the per capita monthly income of their family, comprising the income of all family members living in the same household, including the spouse and the next of kin, does not exceed the prevailing mandatory minimum old-age pension. ${ }^{20,21}$

19 Art. 26. - 29/A. of Legislative Act No. LXXX of 2007 on Asylum.

20 Assets and income shall have the same meaning as defined in Legislative Act No. III of 1993 on Social Administration and Social Provisions.

${ }^{21}$ In 2017, the sum of the prevailing mandatory minimum old-age pension was 28,500 HUF (91 EUR). 
During the reception process, the asylum-seeker is entitled to the following aid and support on the basis of need or their individual circumstances: covered material reception conditions (including room and board at the reception facility, a certain quantity of donated goods, travel allowance, covered funeral costs); health care; reimbursement of the costs of learning and education; and financial aid (including financial support for permanent departure from Hungary).

\subsection{Covering Material Reception Conditions}

The refugee authority provides material reception conditions for the applicants at designated reception facilities. Reception facilities are institutions providing room and board for asylum-seekers and foreign nationals under international protection. At the reception facilities, eligible foreign nationals have access to all the services intended to ensure that their basic everyday needs are properly provided for, as well as access to aid, support and social assistance in conformity with European norms and their individual circumstances throughout their period of eligibility. In the reception facilities asylum-seekers receive accommodation, three meals a day (or an equivalent amount of money as meal allowance), eating utensils and hygiene supplies (or an equivalent amount of money as a hygiene contribution) and, if necessary, clothing. Accommodation in reception facilities is arranged with a consideration to maintaining family unity. During the asylum procedure, the host institution may offer asylum-seekers the opportunity of employment within the confines of the reception centre. For any work contributing to the maintenance and preservation of the reception centre, the foreign national may receive a monthly remuneration of up to $85 \%$ of the prevailing mandatory minimum old-age pension. The refugee authority may accept donations made in money or in kind from natural and legal persons to supplement the budgetary resources made available for services provided to asylum-seekers, refugees, and persons admitted for subsidiary protection and to improve their living conditions, and shall provide for the proper distribution and accounting of such donations. Asylum-seekers are entitled to travel allowance to be used for public transport companies (MÁV-Hungarian State Railways and Volán Coach Transport) in specific cases. The refugee authority shall provide a certificate for the asylum-seeker as specified by the legislation on travel allowance, available at a means of public transportation. The certificate may be issued in cases when the client is in the process of handling administrative 
matters relating to their legal status, when they receive a specific health care service at the competent regional health care service provider, or if they participate in a programme operated by a civil society organisation within the framework of state competences or rely on assistance from such an organisation.

In the event of the asylum-seeker's death, their funeral shall be provided for by the mayor of the municipality where the death occurred, provided that there is no one to provide for the funeral, or such a person cannot be identified or located or is unwilling to provide for the funeral. The refugee authority shall compensate the municipality for the funeral costs.

\subsection{Health care}

If the asylum-seeker is not covered by any social security system and is socially disadvantaged, they are entitled to access specific health care services free of charge. These include the following:

- Primary health care, which is available on site to foreign nationals placed at the reception centre or held in detention in asylum proceedings, or at office of the general practitioner providing health care under the regional service obligation to asylum-seekers placed in private accommodation.

- Age-specific compulsory vaccination.

- Outpatient care (examination, medical treatment, and cost of medicine and dressings) provided in emergency situations. Specialised health care services are available at the health care provider responsible for the given region. Emergency situations refer to any change in the patient's health condition culminating in a potentially life threatening situation or one that would seriously or permanently impair the patient's health in the absence of immediate care.

- Inpatient medical care provided in an emergency (medical treatment, surgical operation, cost of medicine and dressings, and the like).

- Post-care examinations, medical treatment, and medical aids necessary until recovery from illness or a stabilisation of health conditions following outpatient or inpatient medical care.

- Ambulance service, if the patient's health conditions exclude any other form of transportation.

- Emergency dental care and tooth preservation treatment.

- Pregnancy and obstetric care (and in specific cases surgical procedure for pregnancy termination). 
- Medicinal products, medical aids, and dressings prescribed under the fully subsidised public health care system to eligible persons free of charge, or at $90 \%$ or $100 \%$ subsidy.

\subsection{Reimbursement of Learning and Education Costs}

In order to ensure that the children of asylum-seekers receive age appropriate education, the refugee authority covers the costs of their participation in the public education system during their stay at the reception facility, until the person seeking asylum reaches the age of 21. Accordingly, all reasonable costs relating to pre-school, primary school, and secondary school education (or at any other educational institution that meets the child's particular needs) - including the cost of a ticket or pass purchased for purposes of travelling to the educational institution by means of local or long-distance transport, meal costs at the educational institution, and the dormitory accommodation fee - will be reimbursed by the refugee authority.

\subsection{Financial Aid}

The refugee authority may, upon the asylum-seeker's request, cover the asylum-seeker's expenses on the occasion of permanent departure from Hungary. Accordingly, if the person is returning to their country of origin or relocating to a third country permanently, the refugee authority provides a flight ticket on one occasion based on the certificate issued by the diplomatic or consular mission of the country of destination, and may reimburse, partly or fully, any other justified travel-related expense on one occasion.

\subsection{Special Rules by Status}

Provisions and benefits may differ depending on the status of the asylum-seeker, and different provisions and benefits are provided for the different statuses. There are, however, no special rules for persons authorised to stay.

Provisions and Benefits of Refugees and Beneficiaries of Subsidiary Protection. In case of need, the refugee and the beneficiary of subsidiary protection 
are entitled to material conditions of reception, as well as provisions and benefits in order to establish basic living conditions for 30 days from the date of the decision on recognition. In addition, the beneficiary of subsidiary protection is entitled to stay and to provisions at a reception centre or a similar site..$^{22}$ It should be noted that the Act on Asylum was modified in 2016, whereby the duration of these provisions and benefits was reduced from 60 days to 30 days as of 1 June 2016.

Provisions and Benefits of Beneficiaries of Temporary Protection. In case of need, the beneficiary of temporary protection is entitled to material conditions of reception and to provisions and benefits determined in the separate relevant legal regulations. An important difference is that legislation makes it possible to reduce or revoke from these beneficiaries the material conditions of reception provided, as well as the provisions and benefits provided, although this is not possible in the case of refugees or beneficiaries of subsidiary protection.

\section{Conclusion}

The political solution chosen by the government is to keep as many migrants as possible out of Hungary. Although a legal and physical basis for the integration of migrants is available, the policy and its implementation guarantee that most migrants cannot enter the country. The Hungarian government's policy is to allow entry only to refugees under the Geneva Convention.

The evolution of administrative capacities is visible. Public administration has adapted to the new situation but its performance can be qualified controversial. Transit zones and reception centres were established along the borders and next to the main railway stations in Budapest where humanitarian aid was available, but the immigration authority's capacity was not developed. It was unable to conduct an increased number of administrative procedures required to recognise asylum, and more migrants entered the country than the authority was able to register. Before the creation of the fence at the border, people travelling through the country were in many cases given provisions and were supported by the citizens and NGOs.

${ }^{22}$ Art. 32, Section 1 of Legislative Act No. LXXX of 2007 on Asylum. 
As the government decided to keep the problem outside of the country, the border was closed and illegal entry was stopped. In this way, administration of incoming persons was once again placed under the control of the authorities because only asylum applicants may cross the border at checkpoints. The capacities of the immigration authorities and the courts were concentrated as they were placed close to these checkpoints. This permitted administrative decisions and judicial review to be performed on the spot. The special legal rules that were introduced and the special administrative measures that were taken consolidated the operation of public authorities.

By now, asylum-seekers are not even allowed to enter the country until their application for asylum has been positively recognised. They must wait for the decision on their request outside of the country and rejected applicants are turned back. Aid to and integration of asylum-seekers are guaranteed formally, but only to those who manage to cross the border and many of these may easily become subject to asylum detention. While attention is focused on the borders and on sending migrants back from the border, refugees under the Geneva Convention may benefit from the standard services of the state.

\section{References}

\section{Legal sources and documents}

Convention Relating to the Status of Refugees signed at Geneva, on 28 July 1951

Government Decree No. 269 of 15 September 2015 on the Declaration of Crisis Caused by Mass Migration including the Rules Concerning the Mandate, the Existence and the Revocation of Such Situation

Government Decree No. 36. of 6 March 2017 on the modification of the Government Decree No. 41 of 9 March 2016 on the Declaration of Crisis Caused by Mass Migration in the Territory of Hungary including the Rules Concerning the Mandate, the Existence and the Withdrawal of Such Situation

Government Decree No. 361/2016. of 29 November on the Immigration and Asylum Office

Government Decree No. 41 of 9 March 2016 on the Declaration of State of Crisis Caused by Mass Migration in the Territory of Hungary including the Rules Concerning the Mandate, the Existence and the Withdrawal of Such Situation

Legislative Act No. C of 2012 on the Penal Code

Legislative Act No. III of 1993 on Social Administration and Social Provisions 
Legislative Act No. LXXX of 2007 on Asylum

Legislative Act No. XIX of 1998 on Criminal Procedure

Legislative Act No. XXXI. of 1997 on the Protection of Children

Legislative Act No. XXXIX of 2016 on the Modification of Certain Legislative Acts Related to Refugee Affairs

Resolution No. 1043/2017 of 3 February 2017 of the Government on the Assurance of Resources to Increase Professional Police Personnel by 3,000 Persons

Resolution No. 1401/2015 of 17 June 2015 of the Government on Certain Measures Necessary to Manage the Extraordinary Pressure Deriving from Migration

UN General Assembly, Convention Relating to the Status of Refugees, 28 July 1951, United Nations, Treaty Series, vol. 189, p. 137, available at: http://www.refworld.org/docid/3be01b964.html [accessed 25 June 2018]

\section{ADMINISTRATIVE BACKGROUND AND THE PROCESS OF MIGRANT INTEGRATION IN HUNGARY}

\section{Summary}

Some EU member states have been migrant destinations for a long time, while others bave lost a considerable part of their population since their accession to the EU. Hungary belongs to the latter. Large numbers of immigrants bave not been arriving bere since the end of the war in former Yugoslavia. However, in 2015 Hungary was suddenly strongly affected by mass migration, mainly because of the country's geographical location. Mass migration bas strongly influenced politics as the decision-maker and public administration as the executor of political decisions. Both the decisions and the policy-makers bave been strongly criticised for taking a different approach to the situation compared with many other European countries. The Hungarian government's priority was to reduce or stop mass migration and it used political, legal, and physical instruments selected for this purpose. This study does not aim to judge whether they are right or wrong. Hungarian public administration has had to adapt to the situation and it has done so by way of implementing new and modified legal rules. However, due to the political decisions described above, it has developed and changed at the same time.

Keywords: administrative procedure; asylum; immigration authority; mass migration; procedure on the spot; refugees 


\title{
UPRAVNI OKVIR I PROCES INTEGRACIJE MIGRANATA U $M A Đ A R S K O J$
}

\begin{abstract}
Sažetak
Pojedine države članice Eropske unije već su dugo migrantske destinacije dok su druge izgubile znatan dio stanovništva po ulasku u Europsku uniju. Ovoj drugoj skupini pripada i Madarska kamo veći broj useljenika nije pristigao od završetka rata u bivšoj Jugoslaviji. Mađarska je 2015. godine iznenada pogodena velikim priljevom migranata, poglavito zbog svoga zemljopisnog položaja. Masovna je migracija imala snažan utjecaj na politiku kao donositelja odluka i javnu upravu kao izvršitelja. I odluke i donositelji politika našli su se na meti oštrib kritika jer su odabrali drukčiji pristup od mnogih drugih europskih zemalja. Prioritet mađarske vlade bio je smanjiti ili zaustaviti masovnu migraciju te je u tu svrbu odabrala $i$ upotrijebila određena politička, zakonska i fizička sredstva. Cilj ovoga rada nije donijeti sud o njibovoj (ne)opravdanosti. Madarska se javna uprava morala prilagoditi novonastaloj situaciji $i$ to je učinila primjenom novib zakonskih propisa kao $i$ izmjenom postojećib. Nadalje, sobzirom na političke odluke opisane u prethodnom odlomku madarska je javna uprava istovremeno doživjela razvoj $i$ promjene.
\end{abstract}

Ključne riječi: upravni postupak; azil; imigracijske vlasti; masovna migracija; postupak na licu mjesta; izbjeglice 